\title{
Yliopistopedagogiikka ja itse
}

\author{
JUHA HIMANKA
}

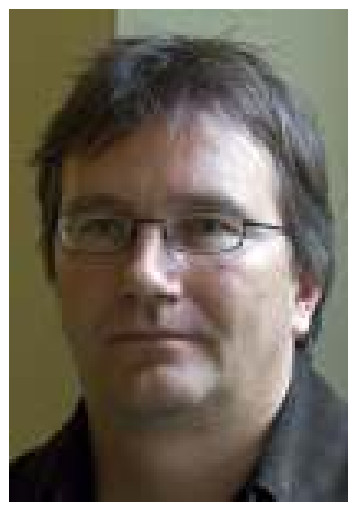

Yliopistopedagogiikan keskeinen käsite reflektio liittyy lähtökohtaisesti itseen. Reflektio on aina itsereflektiota. Tämä alkuperäinen jäsennys ei yliopistopedagogisissa tarkasteluissa kuitenkaan ole juurikaan noussut esiin, ja reflektion käsite on jäänyt epämääräiseksi. Tässä artikkelissa selvitetään, kuinka korkein oppiminen ja itse on liitetty yhteen jo antiikin ajoista alkaen sekä päädytään näkemään Snellmanin yliopistopedagoginen ajattelu tämän kehityksen kulminaationa. liopistopedagogiikka on nuori oppiala, jonka historiaa onkin vain luonnosteltu. ${ }^{1}$ Luonnoksissa ensimmäiset tapahtumat ajoittuvat alle viidenkymmenen vuoden päähän 1960-luvulle, jolloin alalle ryhdyttiin perustamaan omia tutkimusyksikköjä (Neave 1985, Brennan \& Teichler 2008). Nimensä mukaisesti pedagogiikka (kreik. pais/lapsi; agein/ johdatella) on lähtenyt liikkeelle lasten kasvatuksen tutkimuksesta. Aikoinaan yliopistot nähtiin yhteisöinä, joissa sivistystaso tekee opetuksesta oikeanlaista, eikä itsenäiseen opiskeluun olisi edes ollut sopivaa puuttua. Kun yliopistossa sitten ryhdyttiin opettamaan massoja tilanne muuttui ja yliopistossa oppimisen selvittäminen sekä tutkiminen nousi yhteiskunnalliseksi huolenaiheeksi johtaen yliopistopedagogiikan syntyyn oppialana (Neave 1985; Brennan \& Teichler 2008). Vastaava ilmiö käynnistyi astetta korkeammalla, tutkijankoulutuksessa, parikymmentä vuotta myöhemmin.

Itse yliopistopedagogiikan asia, eli kuinka vaativimpia teemoja olisi hyvä opettaa, on kuitenkin ollut ajattelun kohteena jo antiikista asti. Aristoteleelta meille on säilynyt vain sisäpiirin luentomuistiinpanoja, joita ei ollut tarkoitettu julkaistavaksi. 1900-luvun alussa löytyneen papyruksen (P. Oksyrhynkhos 666) voimme kuitenkin päätellä sisältävän katkelman Aristoteleen julkaistusta teoksesta Johdatus filosofiaan (Protreprikos eis tên filosofian), joka antiikissa oli ehkä tunnetuin filosofi- nen teos (Hutchinson \& Johnson 2005²). Tässä katkelmassa Aristoteles toteaa viisauden (fronêsis) syntyvän "oppimisesta ja tutkimisesta, joiden mahdollisuudet filosofia kattaa" (Aristoteles 2008). Tutkimus ja opettaminen tai oppiminen on siis vaativimmissa aiheissa rinnastettu jo ammoisina aikoina. Itse asiassa, kun teemaa hieman pohtii filosofian kannalta huomaa, että filosofia on oikeastaan aina käsitellyt totuuden ja vapauden lisäksi sitä kuinka nämä saavutetaan, kuinka ne opitaan ja opetetaan. Oppialanuorukainen yliopistopedagogiikka ei vielä ole herännyt huomaamaan mahdollisuuksia oppia tieteistä vanhimmalta, filosofialta siitä, kuinka vaativimpia asioita opitaan ja opetetaan.

Delfoin temppelin otsikkokirjoitus, "tunne itsesi" on antiikin kreikan keskeisiä tunnuslauseita. Yliopistopedagogiikassa puolestaan opiskelun itsenäisyys on keskeinen ja toistuva teema. Se, mitä tuolla itsenäisyydellä tarkoitetaan oletetaan itsestään selväksi. Filosofian puolella kysymys siitä, mitä itse tarkoittaa on puolestaan nähty sekä olennaisen tärkeänä että erityisen vaikeana. Vastaava asetelma näkyy sisarkäsitteessä reflektio. Filosofisesti ymmärrettynä reflektio kohdistuu aina itseen tarkoittaen oikeastaan itsereflektiota. Itsereflektion käsitteen ympärille taas voi hyvin kirjoittaa uuden ajan filosofian historian (Gasché 1995). Syventymällä näihin käsitteellisiin syvänteisiin ja 
pohtimalla kuinka Hegelin absoluuttinen reflektio putoaa oman täydellisyytensä kuiluun saatamme hyvinkin etääntyä arkipäivästä. ${ }^{3}$ Tuolloin yliopistopedagoginen reflektointi ilman monimutkaisia käsitteellisiä taustaselvittelyjä voi hyvinkin tuoda asiaan havainnollisuutta. Ehkä asetelma voisi jopa toimia molempiin suuntiin: yliopistopedagogiikka voisi syventää käsitteitään filosofian avulla ${ }^{4}$ ja filosofiassa puolestaan selkiintyisi kuinka käsitteet tulevat toimeen luentosaleissa ja seminaarihuoneissa.

Kuten tulemme näkemään itse on kulttuurissamme paitsi keskeinen niin myös mahdollisimman laaja teema. Siksi aiheeseen on otettava näkökulma, ja onneksemme meillä Suomessa on hyvä kulma tarjolla. J. V. Snellmanin klassinen kirjoitus Akateemisesta opiskelusta (Snellman 2000 [1840], ks. Lehmusto 117-143 ) on kiinni sekä opetuksen käytännössä ja järjestämisessä että filosofisen käsitetyön ytimessä. Snellmanin teksti liittyy kiinteästi hänen toimintaansa yliopistossa ja on näiltä osin hämmästyttävän ajankohtainen (Himanka 2008). Itsen ja reflektion teemojen kulminaatiopisteeksi filosofian historiassa taas on nähty G. W. F. Hegel ja Snellman on nimenomaan hegeliläinen ajattelija. Pedagogiikan ja itsen teemasta yliopiston piirissä on Suomessa myös hiljattain väitelty (Huhtala 2008), mutta varsinaista tematisointia siihen kuka itse on ei ole tehty. ${ }^{5}$

\section{Itse ja oppiminen}

Oppiminen tuli teemaksi jo Aristoteleen opettajalla, Platonilla. Sanastollisesti ensimmäinen meille säilynyt teksti, jossa harjoittelua ja oppimista käytetään toisensa poissulkevasti, on dialogin $\mathrm{Me}$ non alku (Hieronymos 1970): 'Osaatko sanoa, Sokrates, voiko hyvettä opettaa? Tai voiko siihen harjaantua? Vai syntyykö se ihmiseen luonnostaan tai jotenkin muuten, ei siis harjaantumalla eikä oppimalla?" (Platon 1999a; 70a). Dialogissa oppimista sitten selkiytetään havainnollistamalla kuinka palveluspoika oivaltaa geometrisen totuuden, kun Sokrates kysyy häneltä antamatta suoraan vastausta. Eero Salmenkivi on lisensiaatintyössään osoittanut, että tämä Platonin esitys on paitsi hyvin ajan tasalla myös harvinaisen toimiva havainnollistus (Salmenkivi 2003). Tässä kiinnitämme huomiomme erityisesti esimerkin loppuun, jossa Sokrates toteaa palveluspojasta hänen heränneen "tietämään kenenkään opettamatta vain siten, että häneltä kysytään. Hän siis löytää tiedon omasta itsestään.” (85d, oma alleviivaus). Länsimaisen oppimisajattelun avaava dialogi asettaa siis melkoisen painon käsitteelle 'itse'. Mitä me sillä sitten tarkoitamme?

Platonin teosten joukkoon sijoitetussa dialogissa Alkipiades I Sokrates kysyy: "Voimmeko koskaan tietää, mikä taito tekee meidät paremmiksi, ellemme tiedä, mitä me itse olemme?" (Platon $1999 b ; 128$ e). Kysymykseen vastaamisesta muodostui tulkintatraditio jo antiikissa (Schrader 1989). Sana 'itse' on meille kovin tuttu ja mikä voisikaan olla minulle läheisempi ja tutumpi kuin juuri minä itse. Mutta vastaavasti kuin Augustinus huomasi ajan suhteen, ettei kovin tuttuun asiaan ole helppo antaa vastausta, kun sitä kysytään, ei kysymykseen itsestäkään ole helppoa vastata: mitä ihmettä itse on?

Charles Taylor käyttää teoksessaan Sources of the Self (Taylor 1989) yli 500 sivua modernin itsen lähtökohtien avaamiseen, mutta ei ymmärrä tätäkään vastausta mitenkään tyhjentäväksi. Kirjahan ei tosiaan esimerkiksi jäsennä länsimaista käsitystä itsestä suhteessa vaikkapa aasialaisiin, vaikka teoksessa kuvattu maailmantilanne tuntuisi juuri sitä vaativan. ${ }^{6}$ Toisaalta tähän tehtävän käsitteellinen taustatyö on vielä pahasti kesken (Taylor 1989, 535-6 note 4; Schrader 1989). Jo tehtävä ymmärtää, miten erottuvat itsen jäsennys nykyään ja antiikissa, on harvinaisen vaativaa. Kulttuurimme suuret jäsentäjät aina Hegelistä lähtien ovat nähneet keskeisen eron antiikin ja uuden ajan välillä juuri nykyajan individualismissa ja subjekti-keskeisyydessä suhteessa aiempaan. Eron tekeminen ymmärrettäväksi onkin humanistisen alan vaikeimpia ja tärkeimpiä tehtäviä. Hegel havainnollistaa asiaa näytelmillä: antiikin tragedioissa päähenkilöt eivät ratkaise asioita vaan seuraavat kohtaloaan. Uuden ajan näytelmissä roolihahmot ovat subjekteja, jotka päättävät toiminnastaan (Hegel 1986 [1807]). Taylor havainnollistaa eroa esimerkiksi sillä kuinka käsitämme ideat: Platonille kyse on kosmosta jäsentävästä periaatteesta kun taas Descartesille ideat ovat mielessämme (Taylor 1989, 188).

Voimme lähteä jäsentämään itseyttä myös kielen rakenteista. Klassisen kreikan pronominia autos käytetään kolmessa merkityksessä: viittaamaan kolmannen persoonan henkilöön tai asiaan (hän/ se); merkityksessä 'sama' ja merkityksessä 'itse'. Taylor kiinnittää huomiota siihen, että antiikissa termiä autos ei käytetä merkityksessä, joka käännettäisiin englantiin 'a self' (Taylor 1989, 113). 
Antiikissa sanaa tosiaan käytetään lähinnä määreenä, mutta esimerkiksi edellä siteeratussa kohdassa Menonia tullaan lähelle subjektiutta ja Aristoteleen Eudomoksen etiikassa mainitaan toinen itse (allos autos, 1245a30). Myös Aristoteleelle keskeinen noêsis noêseôs, 'ajattelun ajatteleminen' (Schrader 1989) tuntuu tulevan lähelle ajatusta itsereflektiosta ja subjektista. Schrader näkeekin, että substantiivisesti käytetty 'itse' on löydettävissä jo antiikista, mutta jättää auki sen, missä määrin voimme tästä edetä persoonalliseen identiteettiin nykymerkityksessä. Historisches Wörterbuch der Philosophie ei näin uskalla esittää reflektoitiinko antiikissa persoonalliseen identiteettiin tai tietoisuuden ykseyteen eikä myöskään väitä tietävänsä millä käsitteillä tätä olisi tehty (Schrader). Sanakirja ei siksi artikkelinsa alussa anna sanalle Selbst kreikan ja latinan kielisiä vastineita. $^{7}$

Länsimaisen kulttuurin omaisnaispiirre on ollut mallin ottaminen jo päättyneeltä kulttuurilta, antiikista. Yksilön, itsen, persoonan ja subjektin käsitekenttä kuitenkin muodostaa jäsennyksen, joka sijoittuu aivan kulttuurimme ytimeen, muttei mallinnu antiikin esikuvan mukaan, vaikka taustaa tällekin antiikin rikkaasta kokonaisuudesta löytyy. Taylor saattaakin hyvin olla oikeassa nähdessään itsen ja siihen sisäistymisen olevan rinnakkaisilmiö luonnontieteiden vahvistumiselle.

Moderneissa kielissä sanaa itse ryhdyttiin käyttämään ensiksi englannissa 1600-luvun lopulla (Schrader 1989). Kuten tunnettua itsen merkitys persoonana ja ajattelun lähtökohtana syventyi sitten esimerkiksi René Descartesin, John Locken ja David Humen ajattelussa. Tässä artikkelissa suuntaudumme kuitenkin erityisesti itsen ilmaantumiseen saksalaiseen ajatteluun. ${ }^{8}$ Jo Leibniz tematisoi asiaa kommentoidessaan Lockea, mutta tätä tekstiä ei julkaistu hänen elinaikanaan. Vielä Kantillakaan Selbst ei ollut keskeisiä käsitteitä, vaikka se asiallisesti sijoittuu hänen ajattelunsa ytimeen. Kant kuitenkin tematisoi subjektia lähinnä itsetietoisuuden käsitteellä. Hegelillä itse sitten on jo ekplisiittisesti ydinkäsite. (Schrader 1989.)

Saksalaisessa idealismissa itseä siis selvitettiin pitkälti juuri itsetietoisuutena, ja Snellmanin kirjoituksessa Akateemisesta opiskelusta avainkäsite on juuri itsetietoisuus. Koska Snellman oli hegeliläinen, ymmärrämme käsitteen sen erityisessä hegeliläisessä merkityksessä.

Hegelin Hengen fenomenologian ensimmäinen suuri dialektinen liike johtaa tietoisuudesta itsetietoisuuteen (Himanka 2008). Samalla tarkastelu siirtyy yhteisön tasolta yhteisöön. Myös esimerkiksi Taylorille itse on itse vain suhteessa toisiin (Taylor 1989, 35). Hegelille itsetietoisuus ei näin tarkoitakaan niinkään yksilön sisäistä suhdetta itseensä vaan yhteiskunnallisen tunnustamisen intersubjektiivista prosessia (Jaesche 1989). Hegeliläisessä sosiologiassahan itsetietoisuus haluaa toisen tunnustavan hänet itsetietoisuutena ja yhteisö rakentuu juuri tunnustuksen hakemisessa. Hegelille itsetietoisuus on olemassa vain toisen tunnustamana (Hegel 1986 [1807], 145). Näin ymmärrettynä saatan kyllä rationalisoida avoauton tai kalliin käsilaukun hankintaa moninkin tavoin, mutta pohjimmiltani ostin sen koska sitä halutaan. Näin tavoittelen näiden toisten itsetietoisuuksien, jotka haluavat samaa esinettä, tunnustusta. Tunnustuksen hakemiseen sisältyy usein myös kamppailua - Hegelin kuuluisin esimerkki tästä on herran ja rengin dialektiikka, jonka rakenteen voimme nähdä toistuvan historiassa. Esimerkiksi Snellmanin omassa riidassa konsistorin kanssa 1830luvun lopulla voimme ymmärtään kyseen olleen nimenomaan siitä, että Snellman ei suostunut tunnustamaan rehtori Pippingin auktoriteettia eikä Pipping puolestaan tunnustanut dosentti Snellmanin oikeutta itsenäiseen ajatteluun ja toimintaan. Akateemisesta opiskelusta julkaistiin tämän riidan jälkeen ja voidaan lukea Snellmanin toiminnan käsitteellistyksenä (Himanka 2008).

Hegelin itsetietoisuuteen voisimme syventyä useammallakin tavalla. Varhaisessa fragmentissa Hegel väittää, että "parsittu sukka on rikkinäistä parempi; näin ei ole laita itsetietoisuuden" (Hegel, 1986c, 558). Tästä voisimme edetä itsetietoisuuden keskeneräiseen, haluavaan luonteeseen. Mainittu herran ja rengin dialektiikkahan päätyy rengin puolelle, koska herra tyytyy oloonsa, kun taas renki tekee työtä löytäen työstään aina uudelleen itsensä ja kehittyy parsien sukkia itsensä mallin mukaan. Myöhäinen Hegel taas esittää klassisen taiteen esittämien jumalten kuvaavan vapaata itsetietoisuutta (Hegel 1999b, 46). Voisiko antiikin jumaltaruston tosiaan esittää kuvaavan itsetietoisuuden vapautta? Hegelille vapaus avautuu juuri itsestä käsin (esim. Hegel 1996a, 156). Kun tunnen itseni, olen myös vapaa. Olen esimerkiksi helpommin mielikuvamainonnan armoilla, jossen tunne halun ja tunnustuksen rakennetta ja siten paremmin myös itseäni (ks. Mäki-Kulmala 2004). Voin ostaa avoauton tai kalliin käsilaukun myös tietoisena siitä miksi sitä haluan, mutta tällöin olen valinnut sen itsenäisesti enkä vain kulkenut viettieni 
johtamana. Tässä emme kuitenkaan uppoudu Hegelin ajattelumaailmaan, vaan koetamme jäsentää asiaa hegeliläisen mallin mukaan idealistisesti. Hegelillehän idea ei suinkaan tarkoita maailmasta erotettua abstraktia teoriaa vaan käsitteen ja sen läsnäolon ykseyttä (Himanka 2008). Jälkimmäistä koetamme nyt tavoittaa yliopistopedagogiikan puolelta.

Yliopistopedagogiikkaa opettaessa on hyvä pyrkiä tekemään itse opetustilanteista pedagogisesti esikuvallisia. Pyrkimyksessä tietenkin usein myös epäonnistuu, mutta myös siinä - tai ehkä jopa eritoten silloin - tarjoutuu hyvä paikka oppia opettamisesta ja oppimisesta. Tämä kuitenkin edellyttää, että pysähdymme pohtimaan miksi opetustilanne ei toiminut eli reflektoimme oppimista. Malli opetustilanteessa oppimiselle löytyy jo Platonin Menonista, jossa Sokrates opettaessaan palvelijaa kääntyy muutaman kerran isäntä Menonin puoleen keskustelemaan siitä kuinka opetus etenee. Reflektoinnin edellytys on, että opetus on ollut itsenäistä. Jos opetukselle olisi ollut ulkoa annettu tarkka malli ryhmän itsenäisen toiminnan sijaan, ei olisi mieltä miettiä kuinka tilanteen olisi voinut toteuttaa toisin. Opettaja voi reflektoida opetustaan myös yksin jälkikäteen, mutta silloinkin tämä tapahtuu itsenäisesti eli yhteisön kautta. Saatan esimerkiksi miettiä sitä miksi joku vastasi kysymykseen omituisesti tai keskittyi katselemaan ikkunasta. Hegeliläisittäin ymmärrettynä itse on aina yhteisössä ja reflektio edellyttää muita, joiden kautta tilannetta peilataan.

\section{Akateemisesta opiskelusta ja itsetietoisuus}

Snellmanin Akateemisesta opiskelusta erottaa vahvasti toisistaan koulun ja yliopiston (460). Koulussa tavoite on päästä itsetietoisuuteen (sjelfmedvetande), jonka varaan toimiminen yliopistoyhteisössä siten rakentuu. Tekstin keskeinen idea onkin ymmärtää yliopisto erityisenä yhteisönä, jonka toiminta rakennetaan itsetietoisuuksien varaan. Kuinka tällainen yhteisö sitten poikkeaa muista?

Koulussa opetus rakentuu opettajan auktoriteetin varaan. Opettaja kertoo mitä on opeteltava ja oppilas (lärjunge) pyrkii muistamaan nämä asiat. Näin "ensimmäinen opetus ja sivistys perustuu auktoriteetin määräämään oppilaan passiiviseen suhtautumiseen" (460). Koulun tavoite kuitenkin on nousta pois tuosta passiivisuudesta ja "johdattaa oppilas (lärjunge) itse ajatukseen" (ms.). Sitten kun itsetietoisuus on herännyt, on nuorukainen valmis yliopistoon (462). Yliopistossa itsetietoisuus voi ensin ilmetä itsekkyytenä tai egoismina (462-465). Tämän tuomista ongelmista huolimatta opiskelijaa ei pidä palauttaa koulun penkille, kieltää hänen itsetietoisuutensa oikeutusta. Yliopistoyhteisön on tämän sijaan kannustettava opiskelijaa egoismin yli muiden ihmisten ja perinteen kunnioittamiseen. Tämä edellyttää, että itsetietoisuus kieltämisen sijaan tunnustetaan: "[a]inoastaan tunnustamalla itsetietoisuuden oikeutus voidaan itsetietoisuus sovittaa yhteen perinteen kanssa, ja ainoastaan näin ovat tosi tieto ja siveellisyys ajateltavissa." (464) Kirjoitusta edeltäneessä kiistassahan rehtori Pipping kieltäytyi tunnustamasta dosentti Snellmania itsetietoisuutena (Himanka 2008).

Koska yliopisto-opetus ei rakennu auktoriteettiin (466), vaan opiskelijoiden itsetietoisuuden tunnustamiseen muodostuu myös opetuksesta toisenlaista. Aivan kuten Sokrates opetti palvelijapoikaa Snellmanin yliopistossa, opiskelijalle ei kerrota sääntöä tai lainalaisuutta vaan hänen on muodostettava se itse (463). Opettaja ei myöskään vaan listaa oikeaa tietoa vaan selvittää kuinka hän itse on päätynyt totuuteen (466). Yliopistossa "opettajan pitää aina luennoissaan osoittaa, että hänen tietonsa ovat hänen omaa tutkimustaan, ja hänen ei pidä ainoastaan esitellä tuloksia vaan mahdollisimman paljon johdattaa kuulijaa tiellä, jota hän itse on kulkenut. Näin oppilas johdetaan itse käsittämään mitä todellinen tutkimus on ja oppilas näkee opettajan itsenäisyydessä itsetietoisuuden oikeuden tunnustetuksi." (466) Yliopisto-opetuksen lähtökohta on näin opettajan ja opiskelijan itsetietoisuuden keskinäinen tunnustaminen. Opettaja ei vain kunnioita opiskelijaa, ole alentamatta häntä koululaiseksi vaan myös rakentaa opetuksen siten, että opettaja ansaitsee opiskelijalta tunnustuksen opetuksen itsenäisyydestä, opettajan itsetietoisuudesta. Näin opetuksesta ei muodostu vain tiedon välittämistä edelleen eikä opiskelusta tiedon passiivista vastaanottamista vaan molemmat ovat tuotteliaita (460).

Itsetietoisuus on juuri itsetietoisuutena olennaisesti yhteisössä, sekä nykyisessä että menneessä: 'Ihminen voidaan käsittää ajattelevana ja tahtovana subjektina, itsetietoisuutena, ainoastaan yhteydessä annettuun perinteeseen ja olemassa olevaan oikeustilaan, yhteiskuntaan." (459) Pelkkä itsetunne erottaa itsen muista mutta itse- 
tietoisuus on tätä vastoin jotakin enemmän, on yhteisössä (461). Yhteisön olennainen osa ovat myös kanssaopiskelijat, joiden kykyihin opiskelija vertautuu (462). Snellman näkee opiskelijatovereiden opintojen suhteen jopa opettajaa olennaisemmiksi (471). Tässä näkemyksessä opiskelijat eivät ole vastaavassa asemassa kuin lapset perheessä, kuten rehtori Pipping aikanaan asian näki. Sen sijaan opiskelijat muodostavat yhteisön, jossa eivät ainoastaan löydä itse tiedon lainalaisuuksia vaan myös itse muodostavat käyttäytymistapojaan: "opiskelijoiden itsensä tulee harjoittaa akateemista kuria." (474). Yliopistoyhteisössä opiskelija päättää ja ratkaisee itse sekä tiedossa että toiminnassa (463). Itsenäinen toiminta opiskelijayhteisössä on Snellmanille jopa tiedollista puolta tärkeämpää: "Jos on myönnettävä opiskelijoiden suuri vaikutus toisiinsa tieteellisen sivistyksen yhteydessä, pätee tämä sitäkin enemmän sekä hyvässä että pahassa heidän siveellisessä sivistyksessään.” (472) Yliopisto-opiskelu on näin olennaisesti eettistä.

Itse on jo sinällään eettinen käsite: itse voi olla olemassa vain moraalisten kysymysten tilassa (Taylor 1989; 49, 41). Minä voin tehdä käskystä ja pakon edessä kaikenlaista vailla vastuuta, mutta kun esiin nousen minä itse, olen aina myös vastuullinen toiminnastani. Koulussa voimme esimerkiksi määrätä, että esseen pituuden on oltava 400500 sanaa. Yliopistossa opiskelija päättää itse pituuden. Abstraktin egoismin alkutasolla opiskelija saattaa kirjoittaa juuri niin pitkästi kuin hänen mielensä tekee. Näistä ratkaisuista hän saa palautetta ja oppii huomiomaan muut - esimerkiksi esseen arvioinnin vaivan opettajalle - ja päätyy näin yhä paremmin mitoittamaan tekstin sisällön ja pituuden. Päästyään yliopistosta hän osaa sitten kirjoittaa tarkoituksenmukaisen pitkiä tekstejä, eikä kysy tehtävänantajalta sanamäärästä vaan lukijakunnasta päättäen sitten itsenäisesti, lukijat huomioiden tekstin pituuden.

\section{Yliopistopedagogiikan asia itse}

Platon kertoo Seitsemännessä kirjeessään, ettei kirjoittanut varsinaisesta asiasta itsestään (to pragma auto), koska se tulee esiin vain yhteisön keskustelussa. Asiaa itseään on sitten jäljitetty tuhansia vuosia. Myös 1900-luvun fenomenologinen liike pyrki irti uusien kirjojen kirjoittamisesta edeltävistä kirjoista tavoitelleen asiaa itseään: $z u$ den Sachen selbst. Edmund Husserlin ajattelussa asiaksi itsekseen voidaan nähdä transsendentaali subjektiviteetti, eli jotakin itsen suuntaista. Husserl myös näki juuri vastuun ja itsen liittyvän vahvasti toisiinsa (ks. Taylor 1989, 167). Oppilaalleen Dorion Cairnsille Husserl kirjoitti: "Älkää ajatelko, että kirjoitukseni sisältävät muodollisia, opittavia tuloksia vaan ajatelkaa niiden olevan perustoja, joille itse kykenee rakentamaan, menetelmiä työskennellä itse, ongelmia, jotka itse ratkaisee. Tämä itse olette te, sikäli kuin haluatte tulla filosofiksi." (Husserl 1994, 21.3.1930, s. 24.)

Yliopisto-opettajan voi tässä nähdä toimivan Snellmanin näkemyksen mukaan. Ehkä ajatus, että opettajan tulisi yliopistossa kannustaa opiskelijaa olemaan itse, voisi kantaa yliopiston toiminnan jäsentämisessä pitkälle. Opiskelijakeskeisyyshän ymmärretään usein väärin opiskelijoiden asiakkuudeksi eikä heistä itsestään lähteväksi oppimiseksi.

Näimme alussa, että itsen keskeinen rooli oppimisessa nousi esiin jo Platonin Menonissa. Descartes selvittää Järjen käyttöohjeissa, että emme voisi oppia harjoittamaan tiedettä, "ellei järkemme soveltuisi myös itsenäiseen ongelmanratkaisuun". (Descartes 2001, 47). Rousseau puolestaan toteaa Émilessä: 'Kieltämättä saamme asioista paljon selvemmät ja varmemmat tiedot oppimalle ne itsestämme kuin johtamalla niihin toisten opetuksesta." (Rousseau 1933, 323). Rousseaun taustalla Fénelonin teoksessa Les Aventures de Télémaque, joka 1700-luvun Ranskassa oli Raamatun jälkeen luetuin teos, alkuperäinen mentori, Mentor opastaa antaen Telemakhoksen itse tehdä virheensä ja näin oppia. Itse on siis keskeinen käsite länsimaisessa oppimiskäsityksessä myös uudella ajalla. Snellman tuo tähän kuitenkin olennaisen lisän hän yhdistää itsen nimenomaan yliopisto-opintoihin, eikä näin määritä vain oppimista vaan myös ajatusta yliopistosta. ${ }^{9}$

Vaativimman oppimisen tavoitteista löytyy yhä itseys. Esimerkiksi Helsingin yliopiston humanistinen tiedekunta määrittelee väitöskirjan juuri itsenäiseksi opinnäytteeksi. Määritelmä ei ole tyhjä kirjain, sillä käsikirjoituksia arvioivat lausunnot kiinnittävät paljon huomiota työn itsenäisyyteen. Kyse ei juurikaan ole siitä, ovatko käsikirjoitukset oikeassa vaan siitä, kuinka asiaa saadaan itsenäisesti esitettyä ja kuinka väittelijä ottaa itsenäisen roolin tiedeyhteisössä. Yliopistopedagogiikassakin itse ja reflektio toistuvat usein, mutta näitä käsitteitä tematisoidaan harvoin: tehtäväksi ei juuri- 
kaan oteta itsen määrittämistä itsenäisesti tai reflektion reflektointia.

Tässä artikkelissa reflektointi voisi olla esimerkiksi sen pohtimista, kuinka olen sanaa 'itse' itse käyttänyt. Huomaan kirjoittaneeni, että 'Itse yliopistopedagogiikan asia ...." Taylor taas kirjoittaa vastaavasti: "Spinoza himself would have been rather astonished ...." (314) ja "The view Rousseau himself propounded" (359). Kuinka näiden virkkeiden mieli muuttuisi, jos kirjoittaisimme vain "Yliopistopedagogiikan asia ...", "Spinoza would have been ...."; "The view Rousseau propounded"? Entäpä Huhtalan väitöskirjan virke kirjoitustehtävän asettamisesta: "Jag poängterade att de fick skriva så mycket eller så lite som de själva ville." (11). Jos kirjoittaisimmekin "så mycket eller så lite some de ville", niin miten merkitys muuttuisi? Vai muuttuisiko se mitenkään? Tarvitsenko sanaa 'itse' ylipäänsä välttämättä ollenkaan? Mahdollisimman vahvassa mielessä voin kirjoittaa vaikkapa "halusin kirjoittaa sen runon itse"; "osallistuin itsekin kilpailuun", mutta enkö voisi ilmaista kokolailla saman ihan vaan kirjoittaen "minä halusin kirjoittaa sen runon"; "minäkin osallistuin kilpailuun"? Tämän artikkelin viimeiseen viitteeseen kirjoitin kannastani, että Edmund Husserl pitkälti onnistui hyvin vaativassa tehtävässä selvittää kysymyksen 'mitä on luku?' Viitteessä halusin käyttää sanaa 'itse', enkä 'minä', koska tiedän, ettei tiedeyhteisö yleisesti hyväksy tätä kantaa. Halusin osoittaa olevani tietoinen tästä ja kertoa etukäteen olevani valmis kantamaan väitteestä vastuun tiedeyhteisön edessä. Sana itse tekee pienen mutta merkittävän, vastuun ottavan eron.

Husserl tarkastelee lievää eroa, joka kuitenkin on ratkaisevan tärkeä, nyanssina (Husserl 1992a, 34; Husserl 1992b, 147). Yliopiston idean ja yliopistopedagogiikan kannalta tuo lisä, jonka sanan 'itse' käyttäminen tuo virkkeeseen, voisi olla juuri tuo ratkaiseva nyanssi. Tällöin juuri tuo nyanssi nostaa esiin yliopistopedagogisen ajattelun asian itsensä. Filosofian ja tieteen eroa voi jäsentää miettien ajattelun ja tietämisen välistä eroa (Himanka 2002). Tiedollisella kannalla emme voi oikeutetusti uskaltautua väittämään itsen olevan vastaavasti peruskäsite korkeakoulututkimukselle kuin 'luku' matematiikalle ${ }^{10}$ tai 'elämä' biologialle. Voimme kuitenkin käyttää itseä ajatellaksemme korkeakoulututkimuksen kokonaisuutta ja miettiessämme sen lähtökohtia. Tähän tehtävään Snellmanin jäsennys on edelleen ajankohtainen.

European Science Foundationin tuore raport- ti näkee yliopistopedagogisen tutkimuksen perusteissa ongelmia sekä käsitteistössä että menetelmissä (2007). Raportti myös mainitsee mahdollisuuden, että vielä löytäisimme alaa yhdistävän käsitteen (36). Raportissa ratkaisua ongelmiin etsittiin sosiaalitieteistä. Tässä artikkelissa olemme sen sijaan kääntyneet filosofian puoleen, sillä juuri filosofia käsittelee kunkin alan peruskäsitteitä. Ehkäpä 'itse' voisi jopa toimia yliopistopedagogiikan peruskäsitteenä?

\section{Lähteet}

Airas, O. (1956). Yksilö ja hänen suhteensa yhteisöön J.W. Snellmanin historianfilosofiassa.

Aristoteles (2008). Protreptikos. niin \& näin 59, 51.

Brennan, J. \& Teichler, U. (2008). The future of higher education and of higher education research, Higher education looking forward: an introduction. Higher Education, Online First/Springer.

Carrithers, M., Collins, S. \& Lukes, S. (1985). The category of the person. Anthropology, Philosophy History. Cambridge University Press.

Descartes, R. (2008). Järjen käyttöohjeet. Teokset I. Gaudeamus, 39-116.

European Science Foundation (2007). Higher Education Looking Forward. 2007. www.esf. org

Fénélon (1920 [1699]). Les Aventure de Télémaque I-II, Librairie Hachette.

Gasche, R. (1986). The Tain of the Mirror, Derri$d a$ and the Philosophy of Reflection. Harvard University Press.

Hegel, G. W. F. (1986a). Phänomenologie des Geistes. Suhrkamp,Werke 3.

Hegel, G. W. F. (1986b). Vorlesungen über die Ästhetik II. Suhrkamp, Werke 14.

Hegel, G. W. F. (1986c). Jenaer Schrifter 18011807. Suhrkamp, Werke 2.

Himanka, J. (2008). Yliopiston idea ja J. V. Snellman. Kasvatus, 39 (1), 20-30.

Hieronymos, F. (1970). MELETE, Übung, Lernen and angrenzende Begriffe, Dissertation, Basel.

Husserl, E. (1992a). Cartesianische Meditationen, Eine Einleitung in die Phänomenologie. Gesammelte Schriften 8. Felix Meiner, 1-161.

Husserl, E. (1992b). Nachwort. Gesammelte 
Schriften 5. Felix Meiner, 137-162.

Husserl, E. (1994). Briefwechsel, Band IV. Kluwer.

Hutchinson, D. S. \& Johns on, M. R. (2005). Authenticating Aristotle's Protrepticus. Oxford Studies in Ancient Philosophy XXIX, 193294.

Jaeschke, W. (1989). Selbstbewußtsein. Historisches Wörterbuch der Philosophie. Schwabe \& Co. 350-371.

Lehmusto, J. (1926). Snellman kasvatusopillisena ajattelijana. Gummerus.

Martin, J. \& McLellan (2008). The educational psychology of self-redulation: A conceptual and critical analysis. Studies in Philosophy and Education 27, 433-448.

Miller, J. P. (1982). Numbers in Presence and Absence, A Study of Husserl's Philosophy of Mathematics. Martinus Nijhoff.

Mäki-Kulmala, H. (2004). Tiedon Monimuotoisuus. Aikuiskasvatus, 24 (1), 28-35.

Neave, G. (1995). Gentlemen, Scholars, and Administrators, The Rise of the Higher Education Community in Sweden. Journal of Higher Education, 56 (1), 1-25.

Pedersen, O.(1997). The First Universities, Studium generale and the origins of university education in Europe. Cambridge University Press.

Platon (1999a). Menon. Teokset II. Otava, 109-148.

Platon (1999b). Alkibiades I.Teokset VII, 31-83.

Remes, P. \& Sihvola, J. (toim.) (2008). Ancient Philosophy of the Self. Springer.

Rousseau, J. J. (1933). Émile, eli kasvatuksesta. WSOY.

Salmenkivi, E. (2003). Opitaanko totuus?: Platonin vastaus Menonin paradoksiin. Lisensiaatintyö, Filosofian laitos, Helsingin yliopisto.

Schrader, W. H. (1989). Selbst. Historisches Wörterbuch der Philosophie. Schwabe \& Co. 292-305.

Seigel, J. (2005). The Idea of the Self, Thougt and experience in Western Europe since the seventeenth century. Cambridge University Press.

Snellman, J. V. (2000). Akateemisesta opiskelusta. Kootut teokset 2, Edita, 452-476.

Taylor, C. (1989). Sources of the Self, The Making of the Modern Identity. Cambridge University Press.
Waeraas \& Solbakk (2008). Defining the Essence of a university: lessons fromhigher education branding. Higher Education, Online First/ Springer.

\section{Viitteet}

1. Tietääkseni aiheesta ei ole kirjoitettu historiaa, vaikka aihepiirin taustaa onkin hahmoteltu (esim. Neave 1985). Historian kirjoittaminen tarkoittaisi samalla yliopistopedagogiikan määrittämistä. Tilanne on ongelmallinen seuraavalla tavalla: jokainen yleinen määritelmä yliopistopedagogiikan teemasta ja toiminnasta johtaa aina kauemmaksi sekä laajemmalle kuin yliopistopedagogisen tutkimuksen nykyisen itseymmärryksen rajat. Jos määritämme yliopistopedagogiikan esimerkiksi korkeinta kasvatusta koskevaksi tutkimukseksi, huomaamme, että korkeakulttuurit ovat kautta aikain kantaneet suurta huolta tulevien hallitsijoiden kasvatuksesta kulttuurin korkeimmalle tasolle. Jos katsomme, että yliopisto määritelmällisesti on oltava tarjolla muillekin kuin prinsseille, päädymme antiikin Kreikkaan, jonka demokratiassa hallitsijaksi saattoi pääty kuka tahansa kansalainen ja siksi korkeinta koulutusta oli annettava laajalti (Pedersen 1997).

Eikä lie ole aivan mahdotonta edetä muinaiseen Egyptiin ja sieltä säilyneiseen viisaus- tai oppikirjallisuuteen (xxxerja). Tarkemmissa tutkimuksissa päädymmä näissä asioissa esimerkiksi myös muinaiseen Intiaan. Toisaalta saattaisimme esittää, että vasta psykologian synty antoi pedagogiikalle mahdollisuuden varsinaiseen tutkimukseen ja näin voimme rajoittua aloittamaan vuoden 1900 tienoilta (HWP). Tätä vastoin taas asettuu kanta, että pedagogiikka on itse asiassa paremminkin yhteisö- kuin yksilötiede (Martin, J. \& McLellan (2008)).

Loppujen lopuksi kunkin kulttuurin korkein opetus ja oppiminen on niin olennainen osa kyseisen yhteisön toimintaa, että se niveltyy osaksi aivan yleisinta historiaa. Kirjoittajalla on kuitenkin oltava käsitys aiheensa määrittämisestä. Itse käsitän yliopistopedagogiikan tarkoittavan sen, mikä ymmärretään korkeimmaksi opetukseksi sekä oppimiseksi, ajattelua ja tutkimusta sekä näin saavutetun näkemyksen soveltamista ja reflektointia.

'Ymmärretyn' vaatii hieman selvennystä: näin vältämme eurooppakeskeistä ja luonnontiedepainottunutta positiota, jossa väitetään, että korkeaa oppimista olisi alkanut ilmetä vasta meillä ja viimeaikoina. Esimerkiksi eettisestä oppimisesta tai si- 
vistymisessä maailmanhistoriasta löytyy onnistumisia, joista on meille edelleen esikuvaksi, eikä opettaja-oppilas-ketjulle Sokrates-Platon-Aristoteles-Aleksanteri taida ollut vielä löytynyt vertaa.

2. Aristoteleen teoksen taustoista, ks. http:// montejohnson.googlepages.com/protrepticus

3. Heikki Mäki-Kulmala jäsentää reflektiota hegeliläisestä lähtökohdasta selkeästi esimerkillä lapsesta, joka ensin ryhtyy käyttämään äidinkieltään, mutta reflektiivisen asenteen herättyä "alkaa tajuta kielen sääntöjen sopimuksenvaraisuuden ja sanojen symbolisen luonteen”. (Mäki-Kulmala 2004.)

4. Hyvä esimerkki tällaisesta työstä: Martin \& McLellan 2008.

5. Huhtala kyllä lähestyy muutamin paikoin itsen filosofista tematisointia taustoittaessaan käsitettä (Huhtala 2008, 55, 74), mutta syventyminen termin pedagogisiin yhteyksiin filosofian historiassa ei kuulu tutkimuksen alaan.

6. Carrithers, Collins \& Lukes on monitieteinen ja länsimaista näkemystä laajempi kokonaisuus itsen teemasta. Teos pyrkii kasaantumaan Marcel
Maussin viimeisen julkaisun ympärille, mutta eri alojen asiantuntijoiden käsittelyssä esiin nousee lähinnä vaikeus puhua samasta asiasta.

7. Antiikintutkijoiden erilaisista näkemyksistä suhteessa itseen katso Remes \& Sihvola 2008.

8. Ks. Seigel 2005, 295-423.

9. Victor Cousinin asema hegeliläisenä yliopistolaitoksen uudistajana ja ajattelijana Ranskassa suunnilleen samaan aikaan to sin tulee lähelle Snellmanin mietteitä. Myös hänelle itse on keskeinen teema. Ks. Seigel 2005, 472-480.

10. Luvusta on esitetty määritelmiä Eukleideesta alkaen. Itse kuitenkin näkisin, että luku ei lopulta ole tässä mielessä määrittelykysymys vaan pikemminkin selvitettävä fenomenologisesti. Edmund Husserl onnistui vuosikymmenien työn aikana viemään luvun tarkastelun varsin pitkälle ainakin pidemmälle kuin muita teemojaan - ja itse näkisin, että kokonaisjäsennyksen pääpiirteet on jäsennetty Husserlianassa. (Ks. Miller 1982).

\title{
Yhteisöt, yhteisölliset käytännöt ja oppiminen
}

\author{
Seminaari opettajille ja aikuiskouluttajille, tutkijoille ja opiskelijoille \\ 7. joulukuuta 2009 Helsingissä
}

\section{Päivän alustajat:}

dosentti Karin Filander ja professori Marjatta Vanhalakka-Ruoho, yliassistentti Mikko Saastamoinen, yliopettaja Kimmo Mäki, professori Teemu Leinonen ja yliopistolehtori Saara RepoKaarento

Paikka ja aika: klo 8 (ilmoittautumiset) - 16:00 Ammattikorkeakoulu Haaga-Heliassa Itä-Pasilassa

Osallistumismaksu: 50 euroa ja opiskelijat 35 euroa; sisältää osallistumisen, uuden Aikuiskasvatuksen vuosikirjan Yhteisöllisyys liikkeessä, lounaan sekä aamu- ja iltapäiväkahvin.

Ilmoittautumiset: 23.11 . mennessä www. kansanvalistusseura.fi $>$ Seminaarit tai sähköpostitse info@kvs.fi

Järjestäjät: $\quad$ Aikuiskasvatuksen Tutkimusseura ry

Haaga-Helia Ammatillinen opettajakorkeakoulu

Kansanvalistusseura 